\title{
Alveolar Wound Healing after Implantation with a Pool of Commercially Available Bovine Bone Morphogenetic Proteins (BMPs) - A Histometric Study in Rats
}

\author{
Romeu Felipe Elias CALIXTO \\ Juliana Mazzonetto TEÓFILO \\ Luiz Guilherme BRENTEGANI \\ Teresa Lúcia LAMANO-CARVALHO \\ Department of Morphology, Stomatology and Physiology, School of Dentistry of Ribeirão Preto, \\ University of São Paulo, Ribeirão Preto, SP, Brazil
}

\begin{abstract}
The capacity of a commercially available pool of bovine bone morphogenetic proteins (BMPs) to stimulate osteogenesis in the rat alveolar healing was investigated by histometric analysis. Male rats were anesthetized and had their upper incisor extracted. A pool of purified bovine BMPs adsorbed to microgranular resorbable hydroxyapatite was agglutinated with bovine collagen and saline before implantation into the alveolar socket. The implanted and control rats ( $\mathrm{n}=30$ per group) were sacrificed 1 to 9 weeks postoperatively, the hemi-maxillae were decalcified, processed for paraffin embedding and semi-serial longitudinal sections were obtained and stained with hematoxylin and eosin. The volume fraction of alveolar healing components was estimated by a differential point-counting method in histologic images. The results showed that in both, control and implanted rats, the alveolar healing followed the histologic pattern usually described in the literature. Quantitative data confirmed that the BMPs mixture did not stimulate new bone formation in the alveolar socket of implanted rats. These results suggest that the pool of BMPs adsorbed to hydroxyapatite and agglutinated with bovine collagen did not warrant incorporation of the osteoinductive proteins to a slow-absorption system that would allow a BMPs release rate compatible to that of new bone formation, and thus more adequate to osteoinduction.
\end{abstract}

Key Words: bone morphogenetic proteins, alveolar bone healing, xenograft.

\section{INTRODUCTION}

The challenges of the dental clinic include a progressive bone loss following tooth extraction, which can result in an atrophic alveolar bone ridge and cause difficulty to the placement of both conventional and implant-supported prostheses, while osseointegrated implants can barely or not be installed at all (1-4). Therefore, preservation of the alveolar process in areas of tooth loss and adoption of procedures that minimize bone loss or recover the desirable alveolar ridge dimensions are important goals in dental practice which have been achieved by the use of biomaterials (autogenous, allogenic and heterogenous bone grafts, besides a great variety of synthetic materials). In view of the great availability and low cost of bovine bone, allied to the adequate processing that minimizes the risks of infection transmission, Brazilian, Canadian and European companies have produced bovine bone grafts for medical and dental applications $(4,5)$.

The bone matrix is rich in growth factors, among which are the bone morphogenetic proteins (BMPs), that are synthesized and secreted by osteoblasts and incorporated into the matrix during bone formation. The BMPs, released during osteoclastic bone resorption, are capable of inducing differentiation of mesenchymal cells into osteoblasts (osteoinduction), stimulating bone formation in both remodeling and repairing processes

Correspondence: Profa. Dra. Teresa L. Lamano Carvalho, Departamento de Morfologia, Estomatologia e Fisiologia, Faculdade de Odontologia de Ribeirão Preto/USP, Av. do Café S/N, 14040-904 Ribeirão Preto, SP, Brasil. Tel: +55-16-3602-4012. Fax: +55-16-36330999. e-mail: tllc@forp.usp.br 
(6). Over the last decade, 15 structurally related BMPs were recognized in human and in different animal species $(7,8)$. Some of these BMPs appear as a valuable alternative for filling of bone defects, thus overcoming most shortcomings of bone grafts. Experimental studies have suggested that BMPs were effective in the healing of critical-sized bone defects in bones of different natures $(9,10)$. Particularly, recombinant human bone morphogenetic proteins 2 and 7 (rhBMP-2 and rhBMP7) have been utilized with apparent success for healing of bone lesions in orthopedic and dentomaxillofacial clinics (7).

The purpose of this study was to investigate, by means of histometric analysis, the capacity of a pool of commercially available bovine BMPs to stimulate osteogenesis in rat alveolar wound healing.

\section{MATERIAL AND METHODS}

Sixty male Wistar rats (about $250 \mathrm{~g}$ body weight) were anesthetized with 2,2,2-tribromoethanol (Aldrich, Milwaukee, USA; 25 mg/100 g body weight i.p.) and had their upper right incisors extracted. Immediately after tooth extraction, the alveolar socket of half of the animals were filled with a pool of purified BMPs extracted from bovine fetal cortical bone and adsorbed to a microgranular resorbable hydroxyapatite at a 1:20 ratio (Gen-Pro ${ }^{\circledR}$; Genius-Baumer, São Paulo, SP, Brazil). Following the manufacturer instructions, the material was mixed with bovine collagen (Gen-Col ${ }^{\circledR}$; GeniusBaumer) at 1:10 ratio and few drops of sterile saline to obtain a gelatinous final consistence. Spherical granules of approximately $2 \mathrm{~mm}$ diameter were handmade immediately before implantation of one granule per alveolus. After tooth extraction (control group) or extraction + implantation (implant group) the wounds were sutured with mononylon 4-0 (Ethicon; Johnson \& Johnson, São José dos Campos, SP, Brazil) and a single dose $(0.2 \mathrm{~mL}$ per rat, intramuscularly) of antibiotic (Pentabiótico Veterinário; Wyeth, São Bernardo do Campo, SP, Brazil) was administered. The rats were housed under climate-controlled environment $(12 \mathrm{~h}$ light/12 h dark; $22 \pm 3^{\circ} \mathrm{C}$ ) with free access to standard laboratory chow and tap water. All procedures were conducted in compliance with ethical principles for animal research, as approved by institutional guidelines (Protocol 04.1.669.53.4).

The animals were killed with an intraperitoneal overdose of sodium pentobarbital 1, 2, 3 and 9 weeks postoperatively (1st and 3rd weeks $=5$ animals/period, for histological analysis; 2nd and 9th weeks $=10$ animals/period, for histological and histometric analyses) and their heads were immersed in $10 \%$ formalin for $48 \mathrm{~h}$. After fixation, the maxillae were dissected free and the block containing the healing socket was decalcified (4 days in $20 \%$ sodium citrate and $30 \%$ formic acid) and processed for paraffin embedding. Semi-serial longitudinal $6-\mu \mathrm{m}$-thick sections were cut at $60-\mu \mathrm{m}$ intervals and stained with hematoxylin and eosin.

For histometric analysis the degree of new bone formation was estimated at the end of the 2nd and 9th postoperative weeks, by a differential point-counting method, using an integration eyepiece with 100 equidistant points. A total of 500 points were counted in five histological sections per alveolus (final magnification $\mathrm{X} 100$ ), the percentage of points lying on connective tissue and bone trabeculae being proportional to their volume density. In order to avoid bias, the researcher did not know whether the histological sections were from the control or implant groups. Differences among groups were analyzed by the non-parametric KruskalWallis test ( $\alpha=0.05$ for statistical significance) using the GMC statistical software package (available from http://www.forp.usp.br/restauradora/gmc/gmc.html).

\section{RESULTS}

The different phases of the alveolar healing were recognized by histological examination in the socket of control rats, 1 to 9 weeks after tooth extraction. At the end of the 1st week, the sockets were filled with granulation tissue with moderate lymphocyte infiltration; areas of osteoid matrix deposition were observed mainly on the inner surface of the alveolar walls, while abundant coagulum remnants were seen predominantly in the central region. At the 2nd week, concomitantly with progressive new bone formation there was a decrease in the inflammatory infiltrate and blood clot extension. By the end of the 3rd week, a network of thicker bone trabeculae surrounding interconnecting spaces filled with medullary connective tissue were noticed occupying most of the socket, as observed at the end of the 9th week.

In the implant groups, the implanted granules were not identified in the histologic sections and the bone healing process did not show any noticeable 
difference as compared to the control rats. The histometric analysis confirmed the histologic observation that BMPs implant did not interfere with the alveolar bone healing at any of the evaluated periods (Fig. 1).

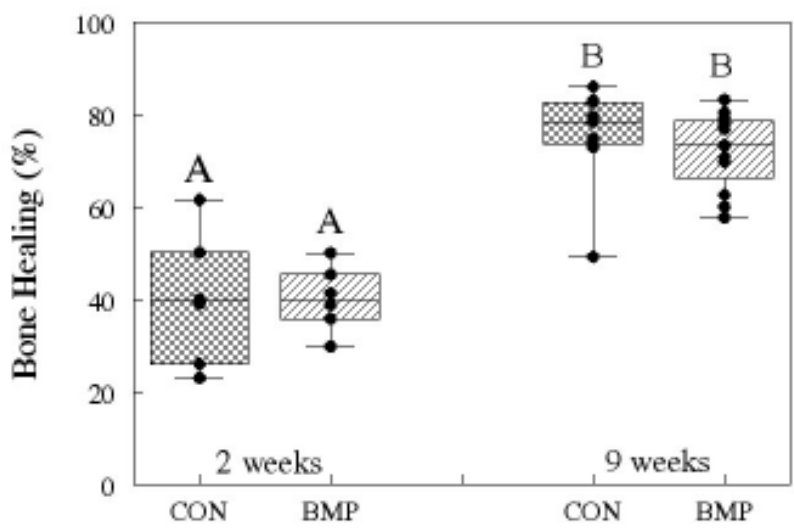

Figure 1. Percent bone healing (median and interquartile intervals) in the alveolar sockets of control (CON) and implanted (BMP) rats, 2 and 9 weeks after dental extraction (Kruskal-Wallis statistical test). Different letters indicate statistically significant differences between the groups ( $A \neq B ; \alpha=0.01)$.

\section{DISCUSSION}

The chronology of the healing process that follows tooth extraction is well established in humans and in different animal species (11-14). Although histologic analyses have suggested that the rat alveolar healing is completed by the end of the 3rd week after tooth extraction (15), quantitative analyses have shown a discrete but significant increase in new bone formation up to the 6th (13) or 8th (12) week. Nevertheless, it has been proved that the major proportion of bone formation (16) and the maximum mineral bone density (11) take place by the end of the 2nd week. In the present study, the histometric analysis of bone healing was carried out at the end of the 2nd and 9th weeks after tooth extraction, thus comprising both the period of maximum new bone formation and the end of the healing process.

The osteoprogenitor cells that migrate into the extraction socket originate from periodontal ligament remnants (14) and/or from the alveolar walls (11), and their differentiation results from the action of growth factors, some of them already present in the blood clot
(14). Among the growth factors controlling bone formation, the BMPs are the only, or at least the most potent osteoinductive elements, which justifies the increasing interest in studies to prove their ability to stimulate bone repair and attest their use as a viable alternative for bone grafts. In spite of its promising potential, one of the major difficulties in utilizing BMPs is their low contents in bone matrix (1 ton of lyophilized bone produces $1 \mathrm{~g}$ of BMPs), which makes BMPs extraction an expensive procedure. Due to the advent of recombinant DNA technology, human BMPs are now available more readily and in larger quantities. Among them, rhBMP-2 and rhBMP-7 have been tested with apparent success by increasing the rate of bone healing in orthopedic and dentomaxillofacial fields (7). Moreover, as many studies have shown that BMPs originating from different animal species present similar osteoinductive capacity, and considering the availability and dimensions of bovine bones, bovine BMPs have also been tested in laboratory investigations and clinical trials (10).

However, another difficulty for the use of BMPs relies on the fact that they are soluble and diffuse rapidly in biological mediums. Therefore, to achieve optimal efficacy, BMPs should be associated with a carrier material that prolongs their residence time at the implant site and allows a release rate compatible to that of new bone formation. In addition to the desirable qualities of a potential BMP-carrier (mechanical stability, malleability and adequate geometry), the ideal carrier material should be osteoconductive and bioactive to stimulate both the differentiation of osteoblasts and the osteogenesis by synergism with BMPs osteoinductive capacity. However, the major characteristics of a carrier should be that it showed be biocompatible, insoluble in tissue media and undergo controlled biodegradation, with retention of BMPs for as much time as necessary for the healing process to be rendered, and release of BMPs in a rate compatible to that of new bone formation $(7-10,17)$.

A wide range of materials have been tested in combination with BMPs, among which are collagen, demineralized or mineral bone matrix and synthetic materials (ceramic, polymers and composites) $(7,8,17)$, although bovine collagen is still the only BMP-carrier approved by American and European regulatory agencies for clinical applications. To our knowledge, there are only two commercially available materials abroad, the rhBMP-2 (InFUSE ${ }^{\mathrm{TM}}$ Bone Graft/LT-CAGE ${ }^{\mathrm{TM}}$ Lumbar Tapered Fusion Device, Medtronic Sofamor Danek, 
Memphis, TN, USA; InductOS ${ }^{\mathrm{TM}}$, Wyeth Europa, Maidenhead/Berkshire, UK) and the rhBMP-7 (Osigraft ${ }^{\mathrm{TM}}$, Howmedica International S. de R.L., Raheen, Limerick, Ireland; NeOsteo ${ }^{\mathrm{TM}}$, Sulzer Orthopaedics Biologics, Wheat Ridge, CO, USA) both in association with absorbable collagen sponges (7). A recent review (7) described the beneficial effects of the rhBMP-2 carried by absorbable collagen sponges, stimulating the healing of diverse bone defects produced in different animals species (including induction of alveolar bone formation for placement of osseointegrated titanium implants in dogs and non-human primates) and for preservation of human alveolar ridge after tooth extraction.

The present study investigated the osteostimulatory capacity of a Brazilian product consisting of a pool of purified bovine BMPs adsorbed to microgranular resorbable hydroxyapatite (serving as carrier), which was agglutinated with bovine collagen (both materials presented as a thin powder) according to the manufacturer instructions. The histologic examination of the alveolar socket collected in some animals in the immediate post-implantation period or after 1, 3, 6 and $24 \mathrm{~h}$ (non-presented data) did not reveal the presence of the implanted granules, even though there was no doubt that they persisted in the alveolar socket after implantation. It is likely that the time elapsed between implantation and fixation of the alveolus (including the suture of the wounds, decapitation, collection of the heads and immersion in formalin, followed by a gradual penetration of the fixative solution) have allowed dissolution of the implanted granules in the blood. In fact, a test carried out by immersion of the granules in fresh blood revealed its rapid dissolution.

The implanted material appeared biologically compatible, as there was neither persistence of the inflammatory reaction nor noticeable histologic difference as compared to the controls. In a study carried out to examine the response of bone marrow to a mixture of biomaterials (18), it was shown that when hydroxyapatite bound to a pool of crude bovine BMPs (containing non collagenous hydrophobic proteins) was mixed with anorganic bovine bone and implanted in the rabbit bone marrow resulted in significantly less new bone formation than after implantation of hydroxyapatite mixed with anorganic bovine bone. The authors discussed that xenogenic proteins others than the BMPs present in crude or semipurified bone extracts could cause an immunologic reaction sufficient to impair osteoinduction and inhibit osteogenesis. This seems not to be the case of the present study because purified bovine BMPs implanted in rats extraction socket did not interfere with the alveolar bone healing.

The results from histometric evaluation did not show significant differences between the control and implant groups when the degree of new bone formation was compared at the end of the 2nd and 9th weeks. In a previous study by Guimarães et al. (19), in which an identical material (GenPro ${ }^{\circledR}$, Baumer S.A.) was added to granules of organic bovine bone matrix and applied to intrabony periodontal defects covered by bovine collagen membrane, the mixture of BMPs adsorbed to microgranular hydroxyapatite did not provide added effects to guided tissue regeneration in terms of clinical parameters. The authors recognized that the actual quantity of the reparative bone could only be determined by histologic analysis but supposed that the hydroxiapatite carrier might have partially interfered with the osteostimulatory capability of the BMPs. In contrast, the same material (GenPro ${ }^{\circledR}$, Baumer S.A) added to granules of anorganic bovine bone and agglutinated with bovine collagen inhibited bone regeneration in segmental defects created in the radial diaphysis of rabbits, as revealed by radiographic and histologic analyses (20). The histologic analysis also revealed the permanence of anorganic bone surrounded by a fibrous capsule up to 150 days after implantation. The authors mentioned studies showing that the use of hydroxyapatite as a carrier to BMPs did not interfere with new bone formation and credited to the anorganic bone particles the unsatisfactory results observed in their study.

In conclusion, it is likely that the mixture of BMPs adsorbed to microgranular resorbable hydroxyapatite and agglutinated with bovine collagen did not warrant incorporation of the osteoinductive proteins to a slow-absorption system that would allow a BMPs release rate compatible with that of bone neoformation, and more adequate to osteoinduction. In this case, the most probable hypothesis is that the amount of BMPs introduced into the dental alveoli was insufficient to stimulate osteogenesis. Other issues that should be addressed are which BMPs were present in the pool and at which ratio.

\section{RESUMO}

No presente trabalho analisou-se histometricamente a capacidade 
de um material de origem nacional em estimular o reparo ósseo alveolar de ratos. Uma mistura de BMPs bovinas purificadas adsorvidas à hidroxiapatita microgranular absorvível foi aglutinada com colágeno bovino e soro fisiológico e implantada na cavidade de extração de incisivos superiores. Os ratos implantados e controles ( $n=30$ por grupo) foram sacrificados após 1, 2, 3 e 9 semanas, as hemi-maxilas contendo os alvéolos em reparação foram descalcificadas e processadas para inclusão em parafina e obtenção de cortes semi-seriados, corados com hematoxilina e eosina. O volume percentual de tecido ósseo reparacional foi estimado por um método de contagem diferencial de pontos, em imagens histológicas analisadas sob uma ocular contendo um retículo com 100 pontos eqüidistantes. Nos ratos controles e implantados o reparo seguiu o padrão descrito na literatura. No grupo implantado, o material não estimulou o reparo ósseo alveolar em nenhum dos períodos analisados. Os resultados sugerem que a mistura de BMPs adsorvidas à hidroxiapatita microgranular absorvível não tenha garantido sua incorporação a um sistema carreador de absorção lenta que propiciasse sua liberação num ritmo compatível com o da neoformação óssea, portanto, adequado à osteoindução.

\section{ACKNOWLEDGEMENTS}

The authors are indebted to Edna A. S. Moraes, Antônio de Campos, Adriana M. G. Silva e Gilberto A. Silva, for technical assistance, and to Genius-Baumer, which gently supplied the implant material. Research supported by CNPq (300599/2003-0).

\section{REFERENCES}

1. Camargo PM, Lekovic V, Weinlaender M, Klokkevold R, Kenney B, Dimitrijevic B, Nedic M, Jancovic S, Orsini M. Influence of bioactive glass on changes in alveolar process dimensions after exodontia. Oral Surg Oral Med Oral Radiol Endod 2000;90:581-586.

2. Christensen GJ. Ridge preservation: why not? J Am Dent Assoc 1996;127:669-670.

3. Perri de Carvalho PS, Bassi APF, Pereira LAVD. Review and proposal of nomenclature for biomaterials. Implant News 2004;1:255-260.

4. Sanada JT, Canova GC, Cestari TM, Taga EM, Taga R, Buzalaf MAR, Granjeiro JM. Histologic, radiographic and imunoglobuline profile analysis after implantation blocks of demineralized bovine cancellous bone graft in muscle of rats. J Appl Oral Sci 2003;11:209-215.

5. Aichelmann-Reidy ME, Yukna RA. Bone replacement grafts: the bone substitutes. Dent Clin North Am 1998;42:491-503.

6. Manolagas SC, Jilka RL. Bone marrow, cytokines and bone remodeling. Emerging insights into the pathophysiology of osteoporosis. New Engl J Med 1995;332:305-311.

7. Geiger M, Li RH, Friess W. Collagen sponges for bone regeneration with rhBMP-2. Adv Drug Deliv Rev 2003;55:16131629.

8. Groeneveld EHJ, Burger EH. Bone morphogenetic proteins in human bone regeneration. Eur J Endocrinol 2000;142:9-21.

9. Caúla AL, Machado F, Barboza E. The potential of recombinant human bone morphogenetic protein-2 (rhBMP-2) in bone regeneration. Rev Bras Odontol 1999;56:185-191.

10. Gonçalves EAL, Guimarães ASC, Garcia RB. Bone morphogenetic proteins: molecular approaches to tissue repair. Braz Oral Res (formerly Rev Odontol Univ São Paulo) 1998;12:299-304.

11. Devlin H. Early bone healing events following rat molar tooth extraction. Cells Tissues Organs 2000;167:33-37.

12. Elsubeihi ES, Heersche JNM. Quantitative assessment of postextraction healing and alveolar ridge remodelling of the mandible in female rats. Arch Oral Biol 2004;49:401-412.

13. Lamano Carvalho TL, Brentegani LG, Bombonato KF. Histometric analysis of rat alveolar wound healing. Braz Dent J 1997;8:9-12.

14. Lin WL, Mcculloch CAG, Cho MI. Differentiation of periodontal ligament fibroblasts into osteoblasts during socket healing after tooth extraction in the rat. Anat Rec 1994;240:492-506.

15. Santos Jr PV, Melhado RM. Effects of ultrasonic stimulation on tooth extraction wound healing: histological study in rats. Rev Odontol UNESP 1990;9:291-299.

16. Guglielmotti MB, Cabrini RL. Alveolar wound healing and ridge remodeling after tooth extraction in the rat: a histologic, radiographic and histometric study. J Oral Maxillofac Surg 1985;43:359-364.

17. Weber FE, Eyrich G, Gratz KW, Maly FE, Sailer HF. Slow and continuous application of human recombinant bone morphogenetic protein via biodegradable poly(lactide-coglycolide) foamspheres. Int J Oral Maxillofac Surg 2002;31:60-65.

18. Costa Filho LC, Taga R, Taga EM. Rabbit bone marrow response to bovine osteoinductive proteins and anorganic bovine bone. Int J Oral Maxillofac Implants 2001;16:799808.

19. Guimarães MCM, Passanezi E, Santana ACP, Greghi SLA. Pool of bovine morphogenetic proteins and guided tissue regeneration in the treatment of intrabony periodontal defects. I - Clinical measurements. J Appl Oral Sci 2004;12:70-77.

20. Ciani RB, Rahal SC, Volpi RS, Taga R, Granjeiro JM, Cestari TM, Mamprim MJ. Mixture of bone morphogenetic proteins, hydroxyapatite, inorganic bone and collagen interposed by pericardium barrier membrane in the filling of the segmental bone defect in rabbits. Arq Bras Med Vet Zootec 2006;58:59-67. 